\title{
Collective Bargaining: A Catalyst for Dispute Resolution between Employers and Employees in the Retail Industry in Urban Mutare
}

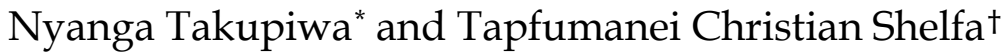

\section{Abstract}

The study assesses the effectiveness of collective bargaining in resolving conflicts between employers and employees in the retail industry. The study shows that collective bargaining is a valuable dispute resolution device in the retail industry. It gives an opportunity to employers and employees to discuss their concerns pertaining to issues of work thereby preventing and resolving disputes amicably. Collective bargaining creates a platform for effective communication, negotiations in good faith, impart knowledge of rights as outlined in the Labour Act Chapter 28:01 and make organisations follow through the collective bargaining agreement (CBA). The study proposes that organisations should ensure that collective bargaining adheres and implements all the CBAs.

Keywords: Collective Bargaining, Collective Job Actions, Collective Bargaining Agreements

\section{Introduction}

An organization's life's span is determined by its ability to tackle and handle its in-house complexities between management and employees. Conflicts and disputes whether in the form of

* Julius Nyerere School of Social Sciences, Great Zimbabwe University, Zimbabwe; takupiwa@gmail.com

† Julius Nyerere School of Social Sciences, Great Zimbabwe University, Zimbabwe; shelfahtapfumanei@gmail.com 
displayed hostility or hidden dissemination are inevitable (Nyanga \& Sibanda, 2015) issues that every organisation must strive to control to ensure uninterrupted production. In light of the increasing number of disputes, most organisations have embraced a number of strategies of resolving disputes, one of which is collective bargaining. The Labour Act Chapter 28:01 set out that collective bargaining is expected to promote peace and democracy in organisations and also resolve workplace disputes. Collective bargaining is one of the methods used to solve industrial disputes in Zimbabwe and the world at large. The Labour Act Chapter 28:01 has made it mandatory for all organisations to bargain with all duly registered trade unions. The retail industry in Mutare urban has been facing a number of work-related disputes and problems which includes among others high rate of employee turnover, absenteeism, low performance and poor internal communication affecting organisational performance. These problems were excavated by organisations rusticated approach to collective bargaining and their failure to establish sound conditions for collective bargaining. Employees and the management have been arranging and having meetings from time to time to negotiate on labour related matters but the results have been partially successful as disputes continue to surge. Collective bargaining is expected to promote peace, harmony and democracy within organisations, but what boggles one's mind is the increasing number of disputes in organisations some of which degenerate into collective job actions such as wild cat strikes, sit-ins, and stay away. The increase in the number of disputes despite the use of collective bargaining to avoid or reduce the intensity of disputes in the retail industry makes it necessary to examine the usefulness and effectiveness of collective bargaining in reducing and resolving organisational disputes.

\section{Literature review}

Collective bargaining is the establishment through negotiation and discussion of an agreement on matters of mutual concern to employers and unions covering the employment relationship, terms and conditions of employment (Armstrong, 2009). In addition, Making (2002) defined collective bargaining as a process of negotiations and bargaining entered into by employees and 
other body and it is covered in the Labor Act Chapter 28:01 section 74. Collective bargaining is defined by Grobbler et al. (2006) as an agreement between employees or their representatives and the management or its' representative, that is written concerning terms of employment. Collective bargaining leads to CBA which when signed by the Minister of labour and social welfare becomes a subsidiary law that governs the relationship between employers and employees in the respective industry. CBA forms the basis of good industrial relations through the promotion of peace, democracy and trust within the industry. Collective bargaining is an essential tool for promoting good working relations within an organisation (Nyanga \& Chifamba, 2012). Owing to the importance of collective bargaining many studies have been conducted about it but however, most studies focused on the relationship between collective bargaining and other variables such as organisational performance, employee motivation, satisfaction and productivity. For instance, Harrison (2004) conducted research which focused on the relationship between collective bargaining and organisational performance in South Africa. A study on collective bargaining by Hurtgen (2003) also noted that the industrial system was adversarial and that capital and labour are always eternally in conflict. Collective bargaining was put in place to stabilise and promote peace in the industry. Collective bargaining as a system of law and regulations was created to channel all forms of labour related conflict into collective bargaining and lawful strikes. In addition, another study was done by Ibietan (2013) in Nigeria which focused on collective bargaining systems in the public sector. He examined the usefulness of collective bargaining in resolving disputes arising from the employment relationship. It was established that collective bargaining was an essential tool to dispute resolution in various work setups.

Block (2003) analysed the impact of collective bargaining on the competitiveness of an organisation. The study shows that collective bargaining influences organisational competitiveness. Organisations should effectively use collective bargaining so as to get a buy-in from employees which in turn gives an organisation a competitive edge. Bello and Kinge (2014) observed that the lack of collective bargaining in organisations is one of the major causes of strike and other forms of collective job actions. Collective 
bargaining plays a pivotal role in reducing collective job actions in organisations, industries and at the national level. In Zimbabwe, the Labor Act Chapter 28:01 section 74 provides information on how collective bargaining should be handled and made it illegal for either the employer or management or union to deny the other party to exercise its rights to collective bargaining. The Labor Act Chapter 28: 01gives management and its representatives the right to negotiate and come up with an agreement to resolve disputes. Nyanga and Chifamba (2012) observed that the extension of collective bargaining goes as far as negotiating disputes over pay, pension payment plan, over time, and non-pay issues such as health and safety, training and development, disciplinary procedures for workers in Zimbabwe.

From the reviewed literature it has been observed that most collective bargaining studies were done in developed countries such as Britain, the United States of America and other upcoming economies such as South Africa and Nigeria. Most of the countries where most of the collective bargaining studies were done have different social, economic, political and geographical contexts with Zimbabwe. In this regard, it is prudent to conduct a similar study in Zimbabwe so that collective bargaining issues are addressed at a more appropriate and local level. Furthermore, most studies focused on variables that influence collective bargaining and its relationship with organisational performance, employee motivation and job satisfaction. There is little if any collective bargaining literature that examined its effectiveness in resolving organisational disputes. It is this yawning knowledge gap which this study aimed to close.

\section{Research methodology}

The study was carried out using the qualitative research approach underpinned with the interpretivism paradigm. Data was gathered using face-to-face semi-structured interviews. Collective bargaining is a sensitive issue hence it requires a research methodology that enhances an in-depth analysis of issues and high levels of confidentiality. The qualitative approach gave the researchers room to probe further and get finer details of issues which in turn increased the validity and worthiness of the results. 
The population of the study comprised approximately 500 employees working in the retail industry in Mutare urban. To get the sample of the study, the researcher had to first use the snowballing sampling technique to get companies that would participate in the study. The researchers first identified one company which then referred them to the other two companies. The other two companies identified three more companies which when the researchers approached them agreed to participate in the study. The process went on until the researchers got 10 (ten) companies that volunteered to participate in the study. Snowballing sampling technique was however not the final sampling method used to come up with the sample; it was followed by the purposive sampling technique which was used to come up with the participants for the research. The researchers selected thirty (30) participants for the study. These participants were permanently employed workers in retail businesses in Mutare urban. The selected participants had a deeper understanding of collective bargaining systems and industrial disputes resolution mechanisms used in retail shops. The participant's experiences helped researchers to gather reliable and valid data which was used to answer the research questions. Individual interviews were done until they reached a data saturation point, the point where there are no new patterns or themes observed with additional data collection (Mason, 2010). Interviews were held at the participants' workplaces, however, there were few exceptions where participants requested to be interviewed at the researcher's workplaces.

\section{Findings}

The study revealed that almost all retail organisations engage in collective bargaining exercises at enterprise and industry levels. Most organisations comply with the provisions of the Labour Act chapter 28;01 to form works councils or participate in National Employment Councils (NEC) activities for purposes of conducting collective bargaining exercises. The establishment of works councils and participating in collective bargaining exercises organised by NEC facilitated the resolution of several workplace disputes. The disputes which most employees and employers 
experienced included disputes of rights and interest. Salaries and wages, overtime, safety clothing and the general conditions of employment topped the list of sources of disputes within organisations.

Below are some of the verbatim quotations of participants; Participants 9 remarked:

"Collective bargaining is useful in our organisation because disagreements on issues to do with salary increments, health and safety, and working conditions have been discussed and resolved amicably."

Participant 24 highlighted:

"Collective bargaining in our supermarket was effective in promoting dispute resolution. It provides a mutual understanding between the two parties creating a good working environment with fewer disputes than anticipated. He further mentioned that the problems are on the management's ability to follow the collective bargaining agreement which would have been made after negotiations".

Participant 39 stated:

"I think that collective bargaining is very useful within the organisation as it is a platform for us to meet with management since we have not yet subscribed to a trade union to represent us. Negotiations are done for everyone who works in the company and gives employees a voice through a workers' committee."

The results show that collective bargaining is a very useful instrument in resolving disputes of interests in organisations. The findings are consistent with (Nyanga \& Chifamba, 2012, Block, 2003, Augar \& Lipsky, 2004) who argue that collective bargaining is a very essential instrument to dispute resolution in any organisation.

The study also revealed that collective bargaining in the retail industry promotes industrial peace, harmony and good industrial relations, which in a way reduce organisational conflict. This implies that collective bargaining directly and indirectly reduces 
and resolves organisational disputes. Those firms which do collective bargaining appropriately resolve their disputes on time and their disputes do not degenerate into collective job actions such as wild cat strikes, picketing, go-slows and stay-aways which directly affect employee satisfaction, creativity, engagement and organisational performance in general. Organisational performance, institutional growth and survival hinges on the ability of an organisation to effectively manage it's negotiation systems on all issues that directly and indirectly affect employees and the organisation. The findings are consistent with Nyanga and Chifamba (2012) who observed that collective bargaining is important to the extent that it can either make or break any organisation irrespective of its size and level of growth. The promotion of industrial peace reduces organisational conflict and reduces the spirit of adversary between employers and employees. In situations where there are industrial peace and harmony, integrative bargaining becomes the main collective bargaining approach where both parties volunteer to share essential information which can help the parties to make informed decisions. The Labour Act 28:01 made it mandatory for employers to have a full disclosure of the organisation's financial status in cases where the employer claims that he/she has no financial capacity to increase workers' salaries, allowances, benefits and wages. The disclosure of essential information help to resolve disputes since both parties will be basing their arguments on the correct and accurate financial position of an organisation. The results concur with Rahim (2001)'s observation that the use of the integrative approach to collective bargaining reduces the psychological distance between employers and employees which cause them to be more prepared to deal with their disagreements in a more constructive manner. The findings of the study, therefore, show that collective bargaining gives employees the chance to have a say in the day to day operation of the organisation and thus management will not always make unilateral decisions on issues which negatively affects employees. Collective decision making results in a peaceful environment since employees feel their presence in the company is appreciated and honoured. Similarly, Augar and Lipsky (2004) observed that collective bargaining is a veritable instrument in ensuring industrial peace and harmony in 
organisations. Therefore, collective bargaining makes employers and employees partners in dispute resolution at the enterprise, regional and national levels.

The study also revealed that collective bargaining propels job satisfaction, which is an essential ingredient to conflict diffusion, avoidance and resolution. Satisfied employees are usually engaged, loyal and committed to their work and organisations. Satisfied employees view their organisation as their own; hence chances of having dysfunctional conflict are limited. Satisfied employees make organisational disputes solved at infancy level.

One of the respondents said: "Collective bargaining propels employee satisfaction. It makes employees happy with their work and makes them feel to be part and parcel of the organisation."

Satisfied employees employ the integrative form of bargaining and engage in constructive and participatory problem-solving negotiations which consequently lead to the resolution of disputes. A win-win approach to collective bargaining leaves both employers and employees happy thereby reducing chances of dysfunctional conflict between employers and employees. The findings are consistent with Nyanga et al (2018) who argued that there is a strong relationship between job satisfaction and collective bargaining. Collective bargaining is, therefore, a very essential tool that promotes job satisfaction among workers and resolves conflicts between employers and employees.

The study further established that collective bargaining gives employees and employers the opportunity to converse about the day to day operation of the organisation which in turn softens their disputes. Regular interaction between trade unions and employers reduce the chances of management from making unilateral decisions on issues that affect employees such as cost of living adjustments, shortage of cash in banks, inadequate supply of resources for use.

Participant 27 remarked:

"For the past five (5) Zimbabwe has been experiencing a serious shortage of cash in banks, which resulted in employees reporting for work late, increased rate of 
absenteeism and presenteeism because workers spend most of their time in bank queues."

Reporting late for work is the main foundation of conflict between employers and employees in the retail industry. The study revealed that conflict between employers and employees in the retail industry that was propelled by economic discord and distress was resolved through collective bargaining. Retail shops had to change their salary management systems by avoiding paying their employees through banks. Collective bargaining was used to resolve cash shortage problems. Employees felt recognised, appreciated and honoured by their employers. The findings concur with Khabo's (2008) observation that by its very nature, collective bargaining "recognises the desirability for joint decision making, joint problem solving and joint responsibility in conducting relations between employers and employees". The findings are consistent with the human needs theory which says that participation is one of the prerequisite needs that should be met if conflicts are to be resolved harmoniously in society and in an organisational setup.

It also emerged from the study that employees have the freedom to meet and discuss workplace issues outside the normal working hours (for example during lunch and tea break periods or any other workplace breaks). The participants highlighted that there are times when they gather together as shop floor workers and present their needs and concerns to the worker's committee who represents them in the discussion of these issues with management. Freedom of assembly and association which is enshrined in Section 58 of the Constitution of Zimbabwe Amendment number 20 Of 2013 gave employees an express right to form unions and workers committees that represent employees interests. This finding corroborates with the human needs theory which says that freedom is a human need which should be taken into consideration if society is endeavouring to live in a harmonious and peaceful environment. In the same vein, in his study in the Nigerian firm, Longe (2015) observed that collective bargaining strategy has been suggested as the approach for managing conflict between employers and employee in organisations. The results of this study show that employees agreed that there is a strong relationship 
between collective bargaining and dispute resolution. The finding further correlates with Bendersky (2003) who reported a significant relationship between collective bargaining and organisational performance and growth.

On the contrary Participant 48 made the following observation regarding the role of collective bargaining in dispute resolution in the retail industry:
"Various factors including management's inability to disclose all information that is relevant to the negotiation and their failure to disclose all information before and during negotiations affect ignite conflict at the workplace".

Failure to bargain in good faith which has become a characteristic of both employers and employees create a hostile environment within the organisation thereby hampering the performance of employees and the organisation in general.

Participant 13 noted:

\begin{abstract}
"They failed to distribute the company budget when we were requesting of a salary increase but they wanted us to believe that they had insufficient funds to increase our salary yet we have never stopped production ever since."
\end{abstract}

Other participants expressively noted that management does not fully understand the provisions of the Labour Act chapter 28:01 and the consequences of failing to implement collective bargaining agreements. Failure by employers to fully understand collective bargaining issues can propel conflict between employers and employees, hence instead of collective bargaining working as a conflict resolution mechanism, it works as a precipitator.

The study further revealed that whilst collective bargaining is regarded as one of the effective catalysts for dispute resolution there are situations where its effectiveness is compromised because of a number of reasons one of which is management's failure to implement a CBA, depriving employees to exercise their fundamental right of freedom of association and depriving employees their right to collective bargaining. The study showed 
that some managers do not create a favourable collective bargaining platform by creating equal collective bargaining opportunities for employers and employees.

Participant 25 remarked:

"Sometimes collective bargaining creates conflict because it involves such tactics as haggling, intimidation and force.

Participant 24 also noted: "Collective bargaining widens the gap between management and workers committees and unions hence it does not resolve disputes."

This implies that collective bargaining can make the two parties create workplace discord because of the differences in employers and employees needs. Depriving employees from participating in union business significantly reduce the chances of resolving conflicts using collective bargaining. Almost all the participants indicated that managers violate the provisions of the Labour Act 28:1 regarding the conduct of collective bargaining and end up failing to adhere to key principles of collective bargaining such as good faith, full disclosure and others. Such behaviour makes collective bargaining fail to resolve organisational disputes. Managers for some retail shops negotiate in bad faith, especially when negotiating for salary increments and cost of living adjustments. Some of the participants in the managerial committee blamed the current hyperinflation in Zimbabwe which contributes to failure by organisations to implement collective bargaining agreements.

\section{Conclusion and recommendations}

The study made the following conclusions: firstly that collective bargaining is an essential catalyst for resolving existing and projected problems and disputes within the organisation. Well managed collective bargaining creates a good corporate image for the employer, mutual trust, prohibits and reduces strikes, balance the business by increasing production and increase employee participation. Secondly, collective bargaining promotes organisational and /or industrial democracy, peace and harmony 
which in turn help to resolve conflicts between employers and employees. In light of the conclusions made the following recommendations were made:

1. Members of management, workers committee and trade unions need to be trained on how collective bargaining should be managed.

2. Organisations should allow their employees to be represented by an appropriate trade union and allow its members to freely participate in union activities so as to allow the free flow of information.

3. Management should fully implement all agreed resolutions reached by both parties during collective bargaining. Employees should be consulted on any future changes or adjustments to CBA so as to ensure that conflicts are avoided or kept at a minimum.

4. The organisation should provide open, honest communication and timely feedback to employees using proper channels on everything that happens in the organisation to ensure good dialogue between management and employees. They should bargain in good faith and disclose all financial documents of the organisation.

\section{References}

Adewole, O. A., \& Adebola, O. G. (2010). Collective bargaining as a strategy for industrial conflict management in Nigeria. Journal for Research in National Development, 8(1), 326-339.

Lipsky, D. B., \& Avgar, A. C. (2004). Collective Bargaining practices: research on employment dispute resolution towards a new paradigm. Conflict Resolution Quarterly Review, 22(3),1-13.

Bello, M. F. \& Kinge, R. F. (2014). Collective Bargaining as a strategy for industrial conflict management in Taraba State Public Services (20012011), Arabian Research Society for Multi-disciplinary, 43(2), 231-246.

Bendersky, L. (2003). Organizational dispute resolution system: A contemporary model. Journal of Business Management, 18(5), 29-38.

Block, R. N. (2003). Bargaining for Competitiveness: Law, Research and Case Studies. W. E Upjohn Institute for Employment Research, Kalamazoo, Michigan. 
Dessler; G. (2015) Human resource management (13 th ed.), Pearson Education, London.

Gwisai, M. (2006). Labour and employment law in Zimbabwe: Relations of work under neoclassical capitalism. Harare: Zimbabwe Labour Centre and Institute of Commercial Law.

Harrison, D. S. (2004). Collective bargaining within the labour relationships in a South Africa context. Pretoria, Vanderbijlpark.

Ibietan, J. (2013). Collective bargaining and conflict resolution in Nigeria's public sector: international relations. Journal of Covenant University, 14(2), 20-33.

Khabo, F. M. (2008). Collective bargaining and labour disputes resolutionIs SADC meeting the challenges? ILO, 30. Harare, ILO (International LabourOrganization) Publications.

Labour Act (Chapter 28:01). Harare: Government Printers.

Lewicki, R. J., Barry, B., \& Saunders, D. M. (2010). Negotiation (6 th $^{\text {th }}$ ), Washington, McGraw-Hill.

Longe, O. (2015). Impact of workplace conflict management on organizational performance: A case of Nigerian manufacturing firm. Journal of Management and Strategy, 76(1), 27-41.

Ojikutu, K. R, Ekwoaba, J. O, \& Ideh, D. A. (2015). collective Bargaining: An Evaluation of Conflict Management Strategies in the University of Lagos, Nigeria. Journal of Economics and Management Sciences, 9(3), 8799.

Nyanga, T., \& Chifamba, E. (2012) Problems and challenges of collective bargaining in the public service in Zimbabwe, teachers' views and perceptions. Journal of Social and Management Sciences, 3(1), 79-97.

Nyanga, T., Mudhovozi, P., Chireshe, R., \& Maunganidze, L. (2012). A survey of job satisfaction of employees at higher learning institutions in Masvingo Province, Zimbabwe. The Anthropologist, 14(1), 73-79.

Nyanga T and Sibanda R (2015) Complexity of organizational conflict: an exploration of implications on sustainable growth in the hospitality industry in Zimbabwe. Journal of Emerging Trends in Economics and Management Sciences (JETEMS), 6(3), 202-208.

Rahim M. A. (2001). Managing conflict in organizations ( $3^{\text {rd }}$ Ed). Westport, Connecticut: Quorum Books.

Taylor J. W. (1986). Profitable collective bargaining. Modern Business Review 4(9), 62-65.

The Constitution of Zimbabwe. Amendment (No. 20) Act (2013). Harare: Government Printers. 